\title{
Dynamic Renal Scintigraphy Results of Pediatric Patients Operated Due to Unilateral Ureteropelvic Junction Obstruction: A Novel Approach to Overestimated Ipsilateral Differentiated Renal Function
}

\section{Sabri Cansaran $\odot$ Ayşenur Celayir $\odot$ Serdar Moralıoğlu ๑ Osman Zeki Pektaş ๑ Oktav Bosnalı ๑}

\author{
Unilateral Üreteropelvik Bileşke Obstrüksiyonu Nedeniyle \\ Opere Edilen Pediatrik Hastaların Dinamik Renal Sintigrafi \\ Sonuçları: Ipsilateral Diferansiye Renal Fonksiyonun \\ Yüksek Ölçümüne Yeni Yaklaşım
}

\section{ABSTRACT}

Objective: The aim of this study was to scintigraphically investigate the preoperative and postoperative renal functions of patients operated due to ureteropelvic junction obstruction, discuss the factors affecting the indication of surgery and emphasize the important points to consider during scintigraphic examination.

Method: We retrospectively analyzed pediatric cases who underwent pyeloplasty due to ureteropelvic junction obstruction. Patients operated for primary ureteropelvic junction obstruction whose preoperative and postoperative dynamic scintigraphy results could be obtained were included in the study. The patients were divided into two groups as those with $<50 \%$ and $\geq 50 \%$ ipsilateral differentiated renal function. The difference between the groups was considered statistically significant when $p<0.05$.

Results: The median ages of 36 cases in $<50 \%$ DRF group and 24 cases in $\geq 50 \%$ DRF group were 7.7 months and 8.5 months, respectively. The mean ipsilateral differentiated renal function values of the main groups were significantly different from each other both in the preoperative and postoperative periods. The changes within the two main groups were also analyzed, yielding significant differences. Ipsilateral differentiated renal function changes on a general, group and subgroup basis, and preoperative ultrasound findings of the ipsilateral kidney in subgroups were revealed.

Conclusion: Increased hydronephrosis degree and renal pelvis anterior-posterior diameter are closely related to overestimated ipsilateral kidney function. For deciding on surgery in patients with ureteral obstruction, scintigraphic examinations make sense with the help of US and the clinical condition of the patient.

Keywords: Dynamic renal scintigraphy, ureteropelvic junction obstruction, pyeloplasty, supranormal function, differentiated renal function, pediatric

Öz

Amaç: Bu çalışmanın amacı, üreteropelvik bileşke obstrüksiyonu nedeniyle opere edilen hastaların preoperatif ve postoperatif renal fonksiyonlarını sintigrafik olarak incelemek, ameliyat endikasyonunu etkileyen faktörleri tartışmak ve sintigrafik inceleme sırasında dikkat edilmesi gereken önemli noktaları vurgulamaktır.

Yöntem: Üreteropelvik bileşke obstrüksiyonu nedeniyle piyeloplasti yapılan pediatrik olgular retrospektif olarak incelendi. Primer üreteropelvik bileşke tıkanıklığı nedeniyle ameliyat edilen ve hem preoperatif hem de postoperatif dinamik sintigrafi sonuçlarına ulaşılabilen hastalar çalışmaya dahil edildi. Hastalar $<\% 50$ ve $\geq \% 50$ ipsilateral diferansiye renal fonksiyonu olanlar olarak iki gruba ayrıldı. Gruplar arasındaki fark $p<0,05$ olduğunda istatistiksel olarak anlamlı kabul edildi.

Bulgular: <\%50 DRF grubundaki 36 olgunun medyan yaşı 7,7 ay ve $\geq \% 50$ DRF grubundaki 24 olgunun medyan yaşı 8,5 aydı. Ana gruplar arasında yapılan karşılaştırmada, ortalama ipsilateral diferansiye renal fonksiyonun hem preoperatif hem de postoperatif dönemde birbirinden anlamlı derecede farklı olduğu görüldü. iki ana grup içindeki değişiklikler de analiz edildi ve anlamlı farklılıklar görüldü. Genel, grup ve alt grup bazında ipsilateral diferansiye renal fonksiyon değişiklikleri, ayrıca alt gruplarda ipsilateral böbreğin preoperatif ultrason bulguları ortaya konuldu.

Sonuç: Artmış hidronefroz derecesi ve renal pelvis ön-arka çapı, fazla ölçülen ipsilateral renal fonksiyon ile yakından ilişkilidir. Üreter obstrüksiyonlu hastaların cerrahi endikasyonu için kullanılan sintigrafik incelemeler US bulguları ve hastanın klinik durumu ile beraber anlam kazanır.

Anahtar kelimeler: Dinamik renal sintigrafi, üreteropelvik bileşke obstrüksiyonu, piyeloplasti, supranormal fonksiyon, diferansiye renal fonksiyon, pediatrik
Received: 15.10 .2020

Accepted: 12.12 .2020

Published Online: 30.04 .2021

Cite as: Cansaran S, Celayir A, Moralığlu S, Pektaş $\mathrm{OZ}$, Bosnalı O. Dynamic renal scintigraphy results of pediatric patients operated due to unilateral ureteropelvic junction obstruction: A novel approach to overestimated ipsilateral differentiated renal function. İzmir Dr. Behçet Uz Çocuk Hast. Dergisi. 2021;11(1):37-42.

Sabri Cansaran Tokat Devlet Hastanesi, Çocuk Cerrahisi Kliniği,

Tokat, Türkiye

sabrican@hotmail.com ORCID: 0000-0001-8466-6595

A. Celayir 0000-0002-7809-4137 S. Moralıŏlu 0000-0003-3374-8229

O. Bosnalı 0000-0003-0485-1374 Sağlık Bilimleri Üniversitesi, Zeynep Kamil Kadın ve Çocuk Hastalıkları Sağlık Uygulama ve Araştırma Merkezi, Çocuk Cerrahisi Kliniği, istanbul, Türkiye

O.Z. Pektaş 0000-0002-9840-4171 Ersoy Hastanesi, Çocuk Cerrahisi Kliniği, istanbul, Türkiye

This study was presented in $35^{\text {th }}$ National Pediatric Surgery Congress, 2017, Edirne/Turkey (VP-66 Award Nominees Session). 


\section{INTRODUCTION}

Scintigraphic diuretic renogram is a highly effective method for visualizing the ureteropelvic junction obstruction (UPJO) and revealing the loss or recovery of renal function. Renal scintigraphy, which can provide information about the degree and level of obstruction, thus contributes to determining surgical indication. Many researchers have shown that most cases of severe hydronephrosis exhibit obstruction in diuretic renogram ${ }^{(1,2)}$. Today, since it is easily applicable from the third week of life and has imaging advantages compared to others, the most preferred agent is Technetium-99m-Mercap-

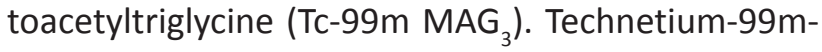
Diethylenetriaminepentaacetic acid (Tc-99m DTPA) also shows $\mathrm{MAG}_{3}$-like behavior, but it cannot be secreted from tubules like $\mathrm{MAG}_{3}{ }^{(3)}$.

Dynamic renal scintigraphy, which provides quantitative data on differentiated renal function (DRF) and obstruction even in hydronephrotic renal units, can be used to diagnose both UPJO and other ureteral obstructions. It is a useful method for longterm monitoring of renal functions.

In this study, it was aimed to scintigraphically investigate the preoperative and postoperative renal functions of patients operated due to UPJO, discuss factors affecting the indication of surgery and emphasize the important points to consider during scintigraphic examination.

\section{MATERIALS and METHODS}

\section{Patient population}

From 2004 to 2017, we retrospectively analyzed pediatric cases who underwent pyeloplasty due to UPJO in a tertiary center. Approval for the study was obtained from the clinical research ethics committee of our hospital. During hospitalization, consent for further clinical studies was obtained from parents. Collected data included patient demographics and scintigraphic/ultrasonographic imaging results.

Surgical intervention is performed for the following indications:

- Symptoms including pain, infection, etc.
- Increase in hydronephrosis grade and decrease in the function of the affected kidney so that it is less than the threshold of 40 percent of split renal function, or there is a serial loss greater than 10 percent.

- Massive hydronephrosis with a renal pelvis anterior-posterior (PAP) diameter $>50 \mathrm{~mm}$ or palpable flank mass (especially in neonates).

\section{Inclusion and exclusion criteria}

Patients operated for primary UPJO whose preoperative and postoperative dynamic scintigraphy results could be obtained were included in the study. The prominent reason for not being able to reach the scintigraphy results of the patients was that the examinations were performed in another center. Cases with UPJO secondary to posterior urethral valve or vesicoureteral reflux, those with solitary kidney or non-functional contralateral kidney (multicystic dysplastic kidney, etc.), bilateral UPJO, recurrent cases and other cases with additional urinary anomalies on the ipsilateral or contralateral sides were excluded from the study. Non-operative follow-up patients were also not included.

\section{Imaging studies}

In our clinic, dynamic renal scintigraphies are routinely performed in UPJO patients during the preoperative and postoperative (6-12 months after surgical repair) periods. While preoperative and postoperative MAG3 dynamic renal scintigraphy results were compared, the patients were divided into two groups as those with $<50 \%$ and $\geq 50 \%$ ipsilateral DRF. The radionuclide excretion patterns in the renogram curve of ipsilateral kidney were evaluated. Arithmetic means of DRF and interval values were calculated in two main groups and four subgroups of age (0-3 weeks, >3-6 weeks, >6-12 weeks and $>12$ weeks). Although dynamic scintigraphic examinations are not considered to yield optimal results under the age of three weeks, we chose to perform them due to patients' rapidly progressing hydronephroses.

Ultrasound (US) is the most used diagnostic tool 
S. Cansaran et al. Dynamic Renal Scintigraphy Results of Pediatric Patients Operated Due to Unilateral Ureteropelvic Junction Obstruction: A Novel Approach to Overestimated Ipsilateral Differentiated Renal Function

in the diagnosis/follow-up process of UPJO patients. The US findings of the patients just before the operation were analyzed. Arithmetic means and interval values of ipsilateral renal pelvis anteriorposterior (PAP) diameters were calculated. The reported hydronephrosis (HN) degrees were evaluated according to Society of Fetal Ultrasound grading system. Subgroup calculations for US findings were performed as previously described.

\section{Evaluation and outcome measures}

Successful outcome was defined as resolution of symptoms, regression of hydronephrosis with parenchymal thickening, reduction of renal PAP diameter and kidney length on US evaluation (at least by 1 grade) and stable US findings with resolution of symptoms or improvement of excretion curve on diuretic renogram (radiological improvement in half-life of the maximum activity $\left[\mathrm{T}_{1 / 2}\right]$ to less than 10 minutes). The patients were called for a follow-up visit every 3 months in the first postoperative year. The follow-up visits were performed every 6 months in the second postoperative year, and then yearly.

\section{Statistical analysis}

Clinical data were recorded in Microsoft OfficeExcel (2016). Mean and interval values were calculated with the same program. Statistical analysis between groups was performed using Fisher's exact test and Student's t-test. The difference between groups was considered statistically significant when $\mathrm{p}<0.05$.

\section{RESULTS}

During the study period of thirteen years, 114 patients underwent pyeloplasty for UPJO. Among these, 60 cases met the inclusion criteria. The median ages of 36 cases in $<50 \%$ DRF group and 24 cases in $\geq 50 \%$ DRF group were 7.7 months ( 8 days11.6 years) and 8.5 months (11 days-9.5 years), respectively. It was remarkable that right sided UPJO was not seen in $\geq 50 \%$ DRF group. Patient demographics are summarized in the Table 1. Clinical presentation consisted of prenatal diagnosis (41), pain (9), incidental (4), urinary incontinence (2), abdominal distension (1), recurrent urinary tract infection (1), cyclical vomiting (1) and fever (1).

In the comparison for the main groups of $<50 \%$ and $\geq 50 \%$ DRF, the mean ipsilateral DRFs significantly differed both in the preoperative and postoperative periods. Mean DRF distribution of the groups is also summarized in Table 1. Ipsilateral DRF was below $10 \%$ in two cases. Postoperative ipsilateral DRF in one of these patients was $30 \%$, while the other's DRF increased, but remained below $10 \%$.

Table 1. Comparison between $<50 \%$ and $\geq 50 \%$ DRF groups. Patient demographics, mean DRFs, interval and $p$ values.

\begin{tabular}{|c|c|c|c|}
\hline Variables & $<50 \%$ group & $\geq 50 \%$ group & $\mathrm{p}$ \\
\hline \multicolumn{4}{|l|}{ Number of patients: } \\
\hline Male & 26 & 21 & 0.21 \\
\hline Female & 10 & 3 & \\
\hline \multicolumn{4}{|l|}{ Number of laterality: } \\
\hline Left & 23 & 24 & 0.0008 \\
\hline Right & 13 & - & \\
\hline $\begin{array}{l}\text { Median age at } \\
\text { surgery (range) }\end{array}$ & $\begin{array}{c}7.7 \text { months } \\
\text { (8 days-11.6 } \\
\text { years) }\end{array}$ & $\begin{array}{c}8.5 \text { months } \\
\text { (11 days-9.5 } \\
\text { years) }\end{array}$ & 0.47 \\
\hline $\begin{array}{l}\text { Preoperative mean } \\
\text { ipsilateral DRF, \% (range) }\end{array}$ & $36(4-49)$ & $56(50-66)$ & 0.00001 \\
\hline $\begin{array}{l}\text { Postoperative mean } \\
\text { ipsilateral DRF, \% (range) }\end{array}$ & $41(5-67)$ & $52(43-59)$ & 0.0002 \\
\hline
\end{tabular}

DRF: Differentiated renal function.

The overall preoperative mean ipsilateral DRF was $44 \%$, which increased to $45 \%$ in the postoperative period $(p=0.33)$. However, mean ipsilateral DRF changed significantly in both main groups. Ipsilateral DRF changes on a general, group and subgroup basis, and preoperative US findings (HN grade, PAP diameter) of the ipsilateral kidney in subgroups are summarized in Table 2.

In all cases, the renogram curve showed a dilated obstructive pattern (plateau form) and $\mathrm{T}_{1 / 2}$ was over 20 minutes. However, in the postoperative period, the renogram curves either returned to normal in most cases or showed a non-obstructive dilated pattern in a small number of the cases. US was routinely used to monitor postoperative change of hydronephrosis. The mean postoperative follow-up 
Table 2. Preoperative/postoperative scintigraphic changes in general, main groups, subgroups, and preoperative US findings in subgroups. Mean DRFs, mean HN grade, mean PAP diameter, interval values, number of cases and $p$ values.

\begin{tabular}{|c|c|c|c|c|c|c|c|c|}
\hline \multirow{2}{*}{$\begin{array}{l}\text { Groups } \\
\text { General } \\
<50 \% \text { DRF } \\
\geq 50 \% \text { DRF }\end{array}$} & \multicolumn{4}{|c|}{$\begin{array}{c}\text { Preoperative mean ipsilateral } \\
\text { DRF, \% }\end{array}$} & \multicolumn{3}{|c|}{$\begin{array}{c}\text { Postoperative mean ipsilateral } \\
\text { DRF, \% }\end{array}$} & $p$ \\
\hline & & $\begin{array}{l}44 \\
36 \\
56\end{array}$ & & & & $\begin{array}{l}45 \\
41 \\
52\end{array}$ & & $\begin{array}{c}0.33 \\
0.0035 \\
0.0003\end{array}$ \\
\hline \multirow[b]{2}{*}{$\begin{array}{l}\text { Subgroups of } \\
\text { age, weeks }\end{array}$} & \multicolumn{3}{|c|}{$<50 \%$ DRF group } & \multicolumn{3}{|c|}{$\geq 50 \%$ DRF group } & \multirow[b]{2}{*}{$\begin{array}{l}\text { Preoperative } \\
\text { mean ipsilateral } \\
\text { HN grade } \\
\text { (range) }\end{array}$} & \multirow[b]{2}{*}{$\begin{array}{c}\text { Preoperative } \\
\text { mean ipsilateral } \\
\text { PAP diameter, } \\
\text { mm (range) }\end{array}$} \\
\hline & $\begin{array}{c}\text { Preoperative } \\
\text { mean ipsilateral } \\
\text { DRF, \% (range) }\end{array}$ & $\begin{array}{l}\text { Postoperative } \\
\text { mean ipsilateral } \\
\text { DRF, \% (range) }\end{array}$ & p & $\begin{array}{c}\text { Preoperative } \\
\text { mean ipsilateral } \\
\text { DRF, \% (range) }\end{array}$ & $\begin{array}{l}\text { Postoperative } \\
\text { mean ipsilateral } \\
\text { DRF, \% (range) }\end{array}$ & $p$ & & \\
\hline $\begin{array}{l}0-3 \\
{[n=6]}\end{array}$ & $\begin{array}{c}39 \\
{[n=1]}\end{array}$ & 33 & - & $\begin{array}{c}57 \\
(54-62) \\
{[n=5]}\end{array}$ & $\begin{array}{c}56 \\
(53-59)\end{array}$ & 0.36 & 4 & $\begin{array}{c}34 \\
(28-38)\end{array}$ \\
\hline $\begin{array}{l}>3-6 \\
{[n=8]}\end{array}$ & $\begin{array}{c}35 \\
(4-48) \\
{[n=7]}\end{array}$ & $\begin{array}{c}37 \\
(5-67)\end{array}$ & 0.53 & $\begin{array}{c}66 \\
{[n=1]}\end{array}$ & 54 & - & $\begin{array}{c}3.7 \\
(3-4)\end{array}$ & $\begin{array}{c}32 \\
(13-47)\end{array}$ \\
\hline $\begin{array}{l}>6-12 \\
{[n=6]}\end{array}$ & $\begin{array}{c}31 \\
(10-48) \\
{[n=4]}\end{array}$ & $\begin{array}{c}31 \\
(10-53)\end{array}$ & 0.75 & $\begin{array}{c}59 \\
(53-64) \\
{[n=2]}\end{array}$ & $\begin{array}{c}50 \\
(47-52)\end{array}$ & 0.2 & $\begin{array}{c}3.2 \\
(3-4)\end{array}$ & $\begin{array}{c}27 \\
(13-43)\end{array}$ \\
\hline $\begin{array}{l}>12 \\
{[n=40]}\end{array}$ & $\begin{array}{c}37 \\
(4-49) \\
{[n=24]}\end{array}$ & $\begin{array}{c}44 \\
(23-54)\end{array}$ & 0.002 & $\begin{array}{c}55 \\
(50-64) \\
{[n=16]}\end{array}$ & $\begin{array}{c}51 \\
(43-57)\end{array}$ & 0.0045 & $\begin{array}{c}3.2 \\
(2-4)\end{array}$ & $\begin{array}{c}28 \\
(12-56)\end{array}$ \\
\hline
\end{tabular}

DRF: Differentiated renal function, HN: Hydronephrosis, PAP: Pelvis anterior-posterior.

period was 4.7 years ( 7 months-9.8 years). All patients are followed-up eventlessly, as described in the methodology section.

\section{DISCUSSION}

The scintigraphic diuretic renogram is one of the important tests used to demonstrate renal function. There are studies showing that diuretic renography with MAG3 is the most suitable method for patients with UPJO after therapeutic interventions ${ }^{(4)}$.

Although scintigraphic examination is an especially useful method in demonstrating obstruction and renal function monitoring, it has various disadvantages, including slight radiation exposure, performance in qualified centers only, and the need for an experienced nuclear medicine specialist for interpretation and evaluation of supranormal function.
Patients with UPJO have lower DRFs on the affected side ${ }^{(5)}$. Supranormal function, seen in $9-22 \%$ of all cases with congenital unilateral hydronephrosis, is defined by $\mathrm{DRF} \geq 55 \%$ in a hydronephrotic kidney $(6,7)$. Today, supranormal function is still controversial. Some authors regard supranormal function as an artifact associated with several factors, such as the use of different radiotracers, the time chosen to accurately predict DRF after radionuclide administration, the identification of relevant areas, the method of calculation or the subtraction of background activity ${ }^{(8-11)}$. Pippi Salle et al. (12) experimentally showed that supranormal function is not an artifact, but a condition based on parenchymal thinning caused by significant hydronephrosis and radioisotope distribution according to the $y$-camera.

DRF measurement is an important parameter in patient management. It is calculated by dividing the values of each kidney by the total value. DRF is 
S. Cansaran et al. Dynamic Renal Scintigraphy Results of Pediatric Patients Operated Due to Unilateral Ureteropelvic Junction Obstruction: A Novel Approach to Overestimated Ipsilateral Differentiated Renal Function

considered normal between $45-55 \%$ and its low rate at the time of diagnosis or decrease in the follow-up process are effective in deciding on surgical treatment (13). In our study, it is noteworthy that $40 \%$ of patients had $50 \%$ or more ipsilateral renal function. An operation decision should not be based on DRF only. In fact, it reflects the accumulation of radionuclide in the pelvic region and may create a false perception as if the function of the ipsilateral kidney exceeds the other. If the contralateral kidney is healthy, it is theoretically not possible to have $\geq 50 \%$ DRF in an ipsilateral kidney showing an obstruction pattern despite diuretic administration. Therefore, based on this hypothesis, we divided our patients into two groups preoperatively as those who showed $<50 \%$ and $\geq 50 \%$ DRF on the ipsilateral side in scintigraphy. Our main goal was to answer this question: Will we be able to find a different result from the studies conducted about the supranormal function to date?

The overall mean ipsilateral DRF increased from $44 \%$ in the preoperative period to $45 \%$ in the postoperative period. A statistically significant increase was observed in mean ipsilateral function in the $<50 \%$ DRF group and a significant decrease was seen in the $\geq 50 \%$ DRF group (Table 2). All these results can be interpreted as indicators of a kidney that tends to normalize after treatment. In particular, the results in the $\geq 50 \%$ DRF group support our hypothesis that the diseased kidney cannot have more function than the healthy kidney in any way.

In subgroup examinations, high $\geq 50 \%$ ipsilateral DRF ratio (83\%) in the 0-3 weeks group is remarkable. Also, with decreasing age, increases in both the mean hydronephrosis degree and mean PAP diameter indicate that these two parameters may be associated with the overestimated ipsilateral DRF (Table 2). A calculation error most likely occurs in patients (especially in neonates) whose kidney size increases due to high grade hydronephrosis. Some authors argued that this was due to reservoir effect of a dilated excretory system and increased renal mass $(8,14,15)$

This study has some limitations, first one being our small sample of patients. This was caused by the inability to obtain the scintigraphy results of numerous patients. We think that this may have affected our subgroup results. The fact that nonoperated patients were not included in the study may also be a limitation. Even though the sample was small, significant conclusions could be drawn. Further studies may be helpful with patients who are both surgically treated and followed up for hydronephrosis.

Dynamic renal scintigraphy is a useful imaging method that can be used actively in the diagnosis and follow-up of patients with ureteral obstruction. Increased hydronephrosis degree and renal PAP diameter (hence increased kidney size) are closely related to overestimated ipsilateral kidney function. Increased ipsilateral kidney function after surgery indicates the success of the operative treatment. Similarly, postoperative loss of function in cases with preoperative $\geq 50 \%$ ipsilateral DRF is not a failure but an indication that the kidney is normalizing. Therefore, instead of focusing only on DRF, the excretion curve must also be evaluated correctly. In patients with ureteral obstruction, dynamic renal scintigraphy is not used alone for surgical indication; scintigraphic examinations make sense with the help of US and the clinical condition of the patient. It may be useful to re-evaluate scintigraphy reports with incorrect interpretations such as $\geq 50 \%$ ipsilateral DRF together with the nuclear medicine specialist. Otherwise, medicolegal problems may be encountered because a kidney with reported $\geq 50 \%$ DRF is operated. In addition, developing a different measurement method, in which the amount retained in the pelvis is measured, for the interpretation of the dynamic scintigraphy may facilitate the work of both nuclear medicine specialists and surgeons in UPJO cases.

Ethics Committee Approval: Approval was obtained from Zeynep Kamil Maternity and Children's Diseases Health Training and Research Center Clinical Research Ethics Committee (26.12.2014/221).

Conflict of Interest: None.

Funding: None.

Informed Consent: Written informed consents were obtained from the parents. 


\section{REFERENCES}

1. Maizels M, Reisman ME, Flom LS, Nelson J, Fernbach S, Firlit $\mathrm{CF}$, et al. Grading nephroureteral dilatation detected in the first year of life: Correlation with obstruction. J Urol. 1992;148:609-14. https://doi.org/10.1016/S0022-5347(17)36668-5

2. Ulman I, Jayanthi VR, Koff SA. The long-term followup of newborns with severe unilateral hydronephrosis initially treated nonoperatively. J Urol. 2000;164:1101-5. https://doi.org/10.1016/S0022-5347(05)67262-X

3. Kass EJ, Fink-Bennett D. Contemporary techniques for the radioisotopic evaluation of the dilated urinary tract. Urol Clin North Am. 1990;17:273-89. https://doi.org/10.1016/S0094-0143(21)00887-9

4. Niemczyk P, Krisch EB, Zeiger L, Marmar JL. Use of diuretic renogram in evaluation of patients before and after endopyelotomy. Urology. 1999;53:271-5.

https://doi.org/10.1016/S0090-4295(98)00494-4

5. Dissing $T H$, Eskild-Jensen A, Pagh C, Frokiaer J, Rehling $M$, Jørgensen $\mathrm{HS}$, et al. Partial unilateral ureteropelvic junction obstruction induced in 2-week-old piglets. J Urol. 2001;166(6):2354-8. https://doi.org/10.1016/S0022-5347(05)65588-7

6. Rickard M, Braga LH, Gandhi S, Oliveria JP, Demaria J, Lorenzo AJ. Comparative outcome analysis of children who underwent pyeloplasty for ureteropelvic junction obstruction associated with or without supranormal differential renal function. Urology. 2017;99:210-4. https://doi.org/10.1016/j.urology.2016.07.016

7. Nguyen HT, Gluckman GR, Kogan BA. Changing the technique of background subtraction alters calculated renal function on pediatric mercaptoacetyltriglycine renography. J Urol. 1997;158:1252-6.

https://doi.org/10.1016/S0022-5347(01)64444-6

8. Inanir S, Biyikli N, Noshari O, Caliskan B, Tugtepe H, Erdil TY, et al. Contradictory supranormal function in hydronephrotic kidneys: fact or artifact on pediatric MAG-3 renal scans?. Clin Nucl Med. 2005;30(2):91-6. https://doi.org/10.1097/00003072-200502000-00004

9. Aktaş GE, Sarıkaya A. Correction of differential renal function for asymmetric renal area ratio in unilateral hydronephrosis. Ann Nucl Med. 2015;29:816-24.

https://doi.org/10.1007/s12149-015-1009-z

10. Aktaş GE, Inanir S. Relative renal function with MAG-3 and DMSA in children with unilateral hydronephrosis. Ann Nucl Med. 2010;24:691-5. https://doi.org/10.1007/s12149-010-0397-3

11. Ham WS, Jeong HJ, Han SW, Kim JH, Kim DK. Increased nephron volume is not a cause of supranormal renographic differential renal function in patients with ureteropelvic junction obstruction. J Urol. 2004;172:1108-10. https://doi.org/10.1097/01.ju.0000135324.17766.5f

12. Pippi Salle JL, Cook A, Papanikolaou F, Bägli D, Breen SL, Charron $\mathrm{M}$, et al. The importance of obtaining conjugate views on renographic evaluation of large hydronephrotic kidneys: an in vitro and ex vivo analysis. J Urol. 2008;180:155965 . https://doi.org/10.1016/j.juro.2008.06.010

13. Özcan Z. The Role of Nuclear Medicine in Pediatric Hydronephrosis. Nucl Med Semin. 2019;5:173-8. https://doi.org/10.4274/nts.galenos.2019.0024

14. Fung LC, McLorie GA, Khoury AE, Ash JM, Gilday DL, Churchill BM. Contradictory supranormal nuclear renographic differential renal function: fact or artifact?. J Urol. 1995;154:667-70. https://doi.org/10.1016/S0022-5347(01)67129-5

15. Capolicchio G, Jednak R, Dinh L, Salle JL, Brzezinski A, Houle AM. Supranormal renographic differential renal function in congenital hydronephrosis: fact, not artifact. J Urol. 1999;161:1290-4. https://doi.org/10.1016/S0022-5347(01)61671-9 